\title{
Marketing Mix Factors Influencing Consumer Behavior on Buying Athlete Shoes in Bangkok
}

\author{
Dr. Chinnaso Visitnitikija, Sontaya Keawbundit \\ Post Graduate School of business administration, Kasembundit University, Bangkok, \\ chinnaso12@gmail.com
}

\begin{abstract}
The purpose of this study is to determine marketing mix factors influencing consumer behavior on buying athlete shoes in Bangkok. Samples were 400 previous customers who bought athletes shoes in Bangkok by using a check list and rating scale questionnaire. The statistics used for data analysis were percentage, mean, standard deviation, Chi-Square, and regression analysis.

On the basis of the results of this study, it could be concluded that most of respondents were males, age 25-35 years old, attended bachelor degree, single marital status, and average income 20,000-30,000 baht. From the study revealed that marketing mix factors influencing consumer behavior on buying athlete shoes in Bangkok was in high level of the opinions, when considered each aspect, the average picture of the opinions on products was in high level with reasons as follows: styles, quality, comfortable and fitted, ventilation, durable, and beautiful colors. Prices aspect, the average picture of the opinions was in high level with reason as follows: appropriate shoes prices, discount prices, comparable to consumer income, and prices suitable to quality. Distribution channel aspect, the average picture of the opinions on distribution channel was in high level with following reasons: there are shoes shops in neighborhood, dealers' nationwide, attractive displays, e-commerce, and available parking spaces. Marketing promotion aspect, the average picture of the opinions on marketing promotion were in high level with followed reasons: there are salesperson to assist on shoes the selection, service after sales, advertising through multimedia, free gift with purchased,

Recommendations from the study were that entrepreneur should emphasis on men and students who usually spend more money on athlete shoes than other group, offer products to meet customers demand, organize an event in shopping department on weekend and holidays, and use multimedia for products advertising.
\end{abstract}

\section{Keyword: Marketing Consumer}

\section{Introduction}

Exercise, sports and recreational activities, broadly to the development of quality of life and society. The government has taken the sports, fitness, and recreation to measure, to promote health, create beautiful features and peace in society, and most important in our society problems nowadays are drug abuse, to prevent and control the spread of drug abuse, and to resolve social problems in the youth group. In addition to sports or exercise, the sports also has helped to create a reputation for yourself and for the nation as well. From these factors which persuaded people to turn into sports more than ever. From these reasons, sports equipment market, especially the market for domestic athlete shoes businesses has been increased in demand which are not only limited to sports consumer, but widespread to those consumer who wear athlete shoes as a fashion.

Currently, sports shoes in Thailand has been increasingly recognized in the domestic market because of a development of production quality standards, and manufacturer have adjusted marketing strategy by building its own brand and give priority to the domestic market even more. Combined with the exercises motivation fitness and health campaign which increased the total value of industrial in 2548. Sports shoes 
industry has developed a material used as a component of the shoes, including the development of color patterns, modern, beautiful styles. Therefore, it will improve in games play as well.

Presently, market producers prioritize domestic market even more, a total market value of 18.6 percent and the potential market direction of sport for growth. The market shares are mainly from consumer emphasis on health care, and their own exercises. In year 2546-2547 government policy that supported public exercise which contributed to stimulate the domestic market expansion, jumped to 18.8 and 15.0 percent, respectively. The expected flow of public health concerned continuously which will result in a market growth for sports shoes 6.3 percent with total market value approximately 3,650 million baht (Economy and Business information, $9^{\text {th }}$ year, number 16, May, 2548, issue). The economic expansion, will be a great opportunity to continue expansion of business in manufacturing in Thailand.

From the competition is not only in domestic market but also in International market which will be the pressure and challenge for Thai manufactures to be certain that the producers will need to be ready in all aspects of business, such as produce with top quality, management with strategy, and control cost of production.

From the introduction above, researcher are interested in the study of marketing mix factors affecting consumer behavior on buying athlete shoes in Bangkok. And bring this study results to be a guideline to develop business strategy in order to provide better services to customer requirement.

\section{Purpose of the Study}

1. To study consumer behavior on purchasing athlete shoes in Bangkok.

2. To determine marketing mix factors influencing consumer behavior on buying athlete shoes in Bangkok.

\section{Conceptual frameworks of the study}

Independent

Variables
Dependent

Variables
Factors of Personal

1. Gender

2. Age

3. Level of education

4. Marital status

Consumer behavior

on purchasing athlete shoes
Factors of Marketing

Mix

1. Products aspect

2. Prices aspect

3. Distribution channel aspect

4. Marketing promotion 


\section{Research Methodology}

\subsection{Sample selection}

Samples were 400 previous customers who bought athletes shoes in Bangkok

\subsection{Data collection procedure}

The questionnaires were distributed to sample of 400 previous customers who bought athletes shoes in Bangkok. A total of 400 usable questionnaires were returned back to the researcher, yielding a 100 percent response rate and no missing data.

The results from the study of marketing mix factors influencing consumer behavior on buying athlete shoes in Bangkok, the average picture of the opinions as shown:

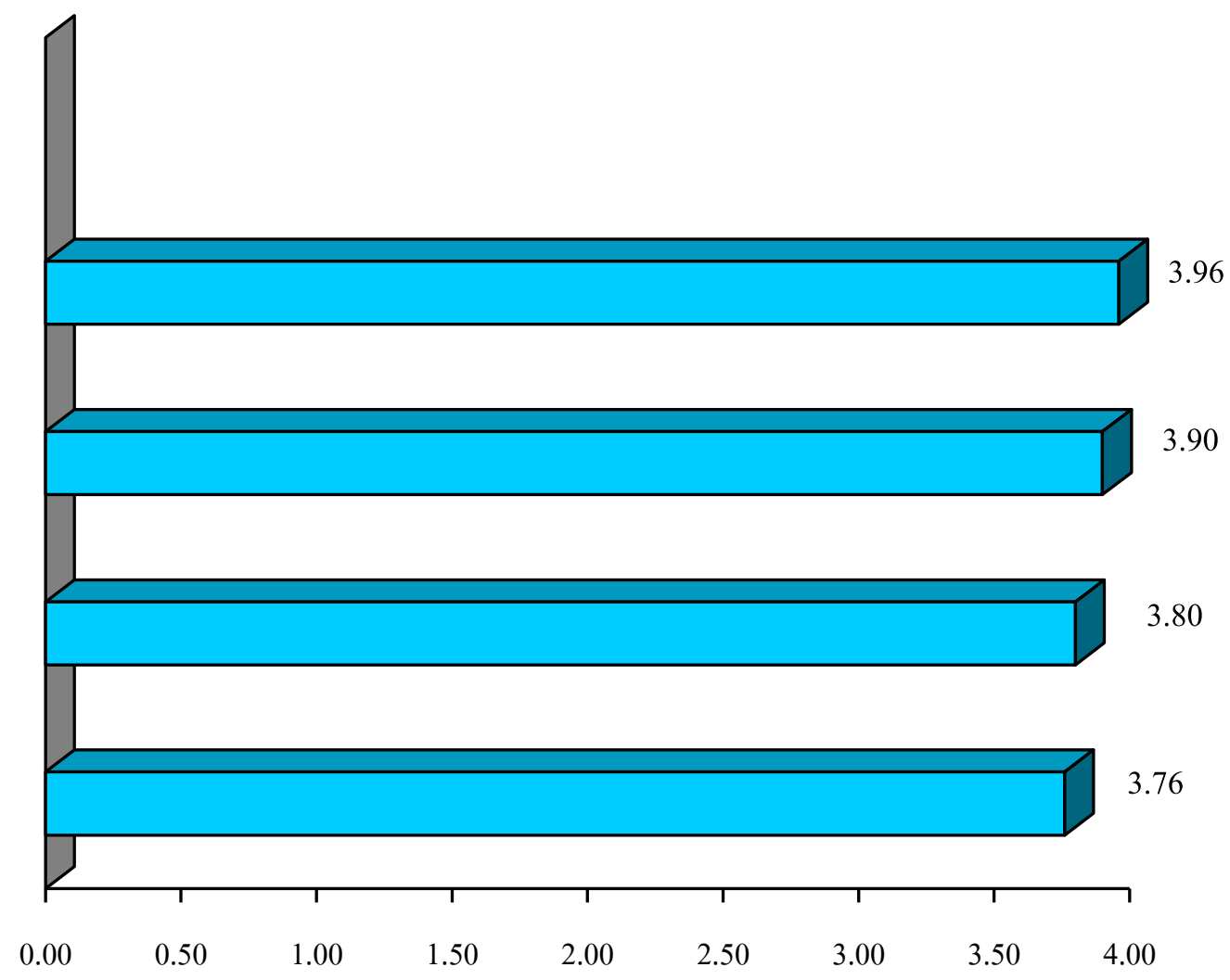

Fig. 1: shows the overall picture of the opinions of marketing mix

From figure 1: shows the average picture of the opinions of marketing mix were at high level $(\bar{x}=3.85)$ as follows: Prices aspect $(\bar{x}=3.96)$, distribution channel aspect $(\bar{x}=3.90)$, marketing mix aspect $(\bar{x}=3.80)$, and products aspect $(\bar{x}=3.76)$.

TABLE I: shows the results from hypothesis testing with regression value of the important of marketing correlated with consumer behavior on buying athlete shoes in Bangkok.

\begin{tabular}{|c|c|c|c|c|c|c|}
\hline $\begin{array}{l}\text { Factors influencing consumer behavior on buying } \\
\text { athlete shoes }\end{array}$ & B & $\begin{array}{l}\text { Std. } \\
\text { error }\end{array}$ & Beta & $\mathrm{t}$ & Sig. & tested \\
\hline (Constant) & .802 & .125 & & 6.399 & $.000^{*}$ & relationship \\
\hline \multicolumn{7}{|c|}{ Products aspect } \\
\hline Shoes styles & .013 & .029 & .011 & .461 & .645 & No relation \\
\hline Shoes quality & -.024 & .027 & -.022 & -.877 & .381 & No relation \\
\hline durable Shoes & .047 & .032 & .048 & 1.484 & .139 & No relation \\
\hline Color & .030 & .022 & .034 & 1.388 & .166 & No relation \\
\hline
\end{tabular}




\begin{tabular}{|c|c|c|c|c|c|c|}
\hline $\begin{array}{l}\text { Factors influencing consumer behavior on buying } \\
\text { athlete shoes }\end{array}$ & B & $\begin{array}{l}\text { Std. } \\
\text { error }\end{array}$ & Beta & $\mathrm{t}$ & Sig. & tested \\
\hline Brand reputation & -.024 & .019 & -.031 & -1.218 & .224 & No relation \\
\hline Shoes ventilation & .041 & .026 & .034 & 1.545 & .123 & No relation \\
\hline Safety when use & .019 & .018 & .023 & 1.042 & .298 & No relation \\
\hline Comfortable and fitted & .126 & .025 & .112 & 4.950 & $.000^{*}$ & relationship \\
\hline Shoes weight & -.062 & .025 & -.073 & -2.430 & $.016^{*}$ & relationship \\
\hline \multicolumn{7}{|c|}{ Prices aspect } \\
\hline Cheap & .089 & .025 & .094 & 3.613 & $.000^{*}$ & relationship \\
\hline Appropriate prices compare to brand names & .092 & .032 & .080 & 2.898 & $.004 *$ & relationship \\
\hline Appropriate prices compare to quality & .088 & .030 & .080 & 2.988 & $.003^{*}$ & relationship \\
\hline Appropriate prices compare to income & .093 & .028 & .086 & 3.355 & $.001 *$ & relationship \\
\hline Discount prices & -.043 & .028 & -.037 & -1.509 & .132 & No relation \\
\hline \multicolumn{7}{|c|}{ Distribution channel } \\
\hline Attractive shop display & .038 & .027 & .036 & 1.401 & .162 & No relation \\
\hline Through e-commerce & .128 & .029 & .117 & 4.453 & $.000^{*}$ & relationship \\
\hline Shops in neighborhood & .098 & .029 & .094 & 3.396 & $.001 *$ & relationship \\
\hline Shops near school/institute & .126 & .032 & .132 & 3.915 & $.000^{*}$ & relationship \\
\hline Available convenient parking spaces & -.039 & .022 & -.051 & -1.786 & .075 & relationship \\
\hline Dealers nationwide & .255 & .031 & .250 & 8.134 & $.000^{*}$ & relationship \\
\hline Promotion with free gift when purchased & -.007 & .019 & -.008 & -.340 & .734 & No relation \\
\hline Salesperson to assist & -.025 & .018 & -.027 & -1.421 & .156 & No relation \\
\hline Service after sales & .000 & .020 & .000 & .016 & .987 & No relation \\
\hline Advertising through television and radio & .085 & .023 & .085 & 3.734 & $.000^{*}$ & relationship \\
\hline Advertising through printing & .047 & .026 & .062 & 1.801 & .073 & No relation \\
\hline Advertising through billboard & .040 & .025 & .051 & 1.593 & .112 & No relation \\
\hline
\end{tabular}

*Significant level 0.05

The test of hypothesis revealed that products aspect, such as comfortable and fitted, light weigh, reasonable prices, prices appropriate to brand names, quality, and income. Distribution channel aspect, such as in neighborhood stores, near school/institute, dealers nationwide, and e-commerce. Marketing promotion aspect, such as advertising through multimedia. The correlation with consumer behavior on buying athlete shoes in Bangkok was at statistical significant 0.05 .

\section{Summary of study results}

On the basis of the results of this study, it could be concluded that most of respondents were males, age 25-35 years old, attended bachelor degree, single marital status, and average income 20,000-30,000 baht.

Consumer behavior on buying athlete shoes were most of respondents have used their athlete shoes for 1-2 years with Nike Brand name for the reasons of durable, and good quality. Salesperson persuaded in selection of the brand name, bought from neighborhood stores, and spent each time about 2000-3000 baht.

Factors of marketing mix affecting consumer behavior in buying athlete shoes were high level of the average picture of the opinion from the respondents with followed reasons:

Products aspect: the average picture of the opinions regarding products were in high level as reasons followed, such as shoes styles, quality, comfortable and fitted, ventilation, durable, light weigh, and beautiful colors.

Prices aspect: the average picture of the opinions regarding prices were in high level as reasons followed, such as prices appropriated to brand names, income, quality, and discounted prices when purchased. 
Distribution channel aspect: the average picture of the opinions regarding distribution channel were in high level as reasons followed, such as dealers located near neighborhood, school/institute, and nationwide. Attractive stores displays and available parking spaces with e-commerce.

Marketing promotion aspect: the average picture of the opinions regarding marketing promotion were in high level as reasons followed, such as salesperson to assisted, service after sales, advertising through multimedia, and free gift when purchased.

\section{Suggestions from the study}

Recommendations from the study were that entrepreneur should emphasis on men and students who usually spend more money on athlete shoes than other group, offer products to meet customers demand, organize an event in shopping department on weekend and holidays, and use multimedia for products advertising.

\section{Suggestions for future research}

This study selected samplings group from consumers in Bangkok district only. Therefore, the future study should select samplings group from different demographic area and bring data to compare and get the results to set a new guideline to benefit of all consumers and entrepreneur.

\section{References}

[1] Kalya Vanichbuncha. (2544-2546). Statistics analysis: Statistic for decision making. $5^{\text {th }}$ edition, Chulalongkorn University, Bangkok.

[2] Dara Tepapal. (2542). Marketing of Consumer behavior, Thaiwatanapanich, Bangkok.

[3] Nopparat Tricunta. (2537). The important factors influencing consumer behavior on buying Athlete shoes. Thesis, Graduate school, Thammasart University.

[4] Borvorn Chaitanakarnkul. (2543). The study of consumer behavior on buying athlete shoes In Bangkok, Thesis, Graduate school, Thammasart University.

[5] Pimolphan Nuekeaw. (2550). Consumer behavior on choosing running shoes in Bangkok, Chiengmai University.

[6] Siriwan Saerirat. (2550). The basic of consumer behavior issue. Visitwattana printing, Bangkok.

[7] Adul Jaturongcakul. (2543). The Strategic of marketing management. $2^{\text {nd }}$ edition, Thammasart University printing, Bangkok. 